\title{
IMPLEMENTASI BIOSISTEM UNTUK PENGOLAHAN AIR LIMBAH LAUNDRY
}

\author{
I Kadek Widiantara ${ }^{1 *}$, I Wayan Budiarsa Suyasa ${ }^{2)}$, I Wayan Diara ${ }^{3)}$ \\ ${ }^{1)}$ Program Studi Magister Ilmu Lingkungan Universitas Udayana \\ 2)Fakultas Matematika dan Ilmu Pengetahuan Alam Universitas Udayana \\ 3) Fakultas Pertanian Universitas Udayana \\ *Email : offroad0809@gmail.com
}

\section{ABSTRACT \\ BIOSYSTEM IMPLEMENTATION FOR WATER TREATMENT LAUNDRY}

Population growth followed by an increase in laundry activity generates waste if left unchecked will cause damage to aquatic biota. To overcome this need the existence of an environmentally benign laundry water treatment system such as biosystem. Biosystem used in this research with length $180 \mathrm{~cm}$ width $60 \mathrm{~cm}$ and height $40 \mathrm{~cm}$ filled gravel as filter media and elephant grass (pennisetum purpureum) plant. The way of operating the biosystem is by pouring the waste into a tub of biosystem and then samples waste water taken on the biosystem output. The result treatment that biosystems combined with anaerobic reservoirs decreased BOD, COD, phosphate and detergent levels by $127.09 \mathrm{mg} / \mathrm{l}, 161.96 \mathrm{mg} / \mathrm{l}, 0.8699 \mathrm{mg} / \mathrm{l}$ and $1.3228 \mathrm{mg} / \mathrm{l}$ in a single treatment on roughing horizontal flow filter for laundry water treatment. The performance of physical and biological components in biosystems combined with anaerobic reservoir effectively decreased BOD, COD, phosphate and detergent concentrations by $73.91 \%, 69.58 \%, 58.74 \%$ and $80.03 \%$ (above $50 \%$ ) in one treatment. But only in lowering the effectiveness of phosphate levels is still relatively low when compared with the effectiveness of wastewater quality standards.Further research needs to be done calculations to find plants in biosystems that can thrive. In addition, further research is needed to find the operating time until the biosystem undergoes a breaktrough condition.

Keywords: laundry, waste water, biosystem.

\section{PENDAHULUAN}

Pertumbuhan penduduk dan pembangunan diikuti oleh peningkatan berbagai aktivitas dan kegiatan usaha untuk memenuhi kebutuhan hidup manusia, tidak dapat dihindari dampak ikutan dari peningkatan pembangunan tersebut adalah timbulnya limbah yang berdampak pada terjadinya peningkatan pencemaran.

Aktivitas masyarakat yang semakin tinggi, mendorong munculnya usaha-usaha yang bertujuan meringankan beban masyarakat dalam hal kerumahtanggaan, seperti jasa laundry atau pencucian pakaian. Kemunculan jasa laundry ini selain dapat memberikan keuntungan, juga menghasilkan limbah dengan volume yang cukup besar.

Pada beberapa tahun belakangan ini perkembangan usaha laundry di kota-kota besar sangat pesat. Seperti halnya jumlah populasi usaha laundry yang ada di kota Denpasar pada tahun 2013 sebanyak 616 pengusaha laundry dan jumlahnya meningkat pada tahun 2015 menjadi 762 pengusaha laundry (BLH Kota Denpasar, 2015). Jika pertumbuhan usaha laundry ini dibiarkan tanpa dilakukan pengawasan dan penanggulangan terhadap limbah yang akan dihasilkan nanti maka pencemaran lingkungan tidak bisa dihindarkan.
Berdasarkan hal tersebut menimbulkan ide untuk mengadakan penelitian pengolahan limbah dengan biosistem sebagai biofiltrasi yang dipadukan dengan bak penampungan anaerob untuk pengolahan air limbah laundry, dengan meneliti tentang penurunan kadar BOD, COD, fosfat dan deterjen pada keluaran biosistem yang digunakan. Adapun tujuan penelitian ini adalah (1) Untuk mengetahui kemampuan biosistem yang dipadukan dengan bak penampungan anaerobdalam menurunkan kadar BOD, COD, fosfatdan deterjen pada roughing filter aliran horizontal untuk pengolahan air limbah laundry (2) Untuk mengetahui efektivitas biosistem yang dipadukan dengan bak penampungan anaerob dalam menurunan kadar BOD, COD, fosfatdan deterjen pada limbah laundry.

\section{METODOLOGI}

\subsection{Lokasi dan Waktu Penelitian}

Penelitian ini dilaksanakan di wilayah Kota Denpasar yang meliputi Denpasar Utara, Denpasar Timur, Denpasar Selatan dan Denpasar Barat. Penentuan sampel ditentukan secara purposive dengan pertimbangan bahwa perkembangan usaha laundry di Kota Denpasar sangat pesat dan lokasi 
dari usaha laundry ini terletak merata hampir di semua tempat dengan karakteristik yang tidak jauh berbeda yaitu mengalirkan air limbah laundry ke lingkungan tanpa dilakukan pengolahan terlebih dahulu. Penelitian dilaksanakan mulai April - Juli 2017 terhitung mulai dari tahap persiapan sampai pembahasan hasil penelitian.

Lokasi pengambilan sampel air limbah laundry dilakukan di saluran pembuangan perusahaan laundry yang diambil secara acak di kota Denpasar. Pengoperasian biosistem dilakukan di Griya Agung Tranggana Manuaba dusun Guliang Desa Pejeng Kecamatan Tampaksiring Kabupaten Gianyar Provinsi Bali. Untuk analisis sampel dilaksanakan di Laboratorium Dinas Kesehatan Provinsi Bali.

\subsection{Prosedur Penelitian}

Prosedur penelitian yang dilakukan, yaitu persiapan penelitian yang meliputi penyiapan biosistem, penyiapan peralatan sampel air,personil pengambil sampel air,dan transportasi. Selanjutnya dilakukan pengambilan sampel air limbah pada usaha laundry dan pengujian kualitas air di Laboratorium Kesehatan Provinsi Bali.

\subsection{Prosedur Analisis}

Proses analisis data dilakukan melalui analisis kualitatif dengan membandingkan hasil pengolahan menggunakan biosistem yang dipadukan dengan bak penampungan anaerob dengan baku mutu air limbah berdasarkan Peraturan Gubernur Bali No. 16 Tahun 2016.

\section{HASIL DAN PEMBAHASAN}

\subsection{Kemampuan Biosistem yang Dipadukan dengan Bak Penampungan Anaerobdalam Menurunkan Kadar BOD, COD, Fosfatdan Deterjen Pada Roughing Filter Aliran Horizontal Untuk Pengolahan Air Limbah Laundry}

\subsubsection{Penurunan Kadar BOD}

Biogical oxygen demand (BOD) atau kebutuhan oksigen biologis (KOB) adalah suatu analisa empiris yang mencoba mendekati secara global proses-proses mikrobiologis yang benar-benar terjadi dalam air. Angka BOD adalah jumlah oksigen yang dibutuhkan bakteri untuk menguraikan (mengoksidasikan) hampir semua zat organis yang terlarut dan sebagian zat-zat organis yang tersuspensi dalam air (Alaerts, 1987).

Pada penelitian ini sudah diuji kemampuan biosistem yang dipadukan dengan bak penampungan anaerobdalam menurunkan kadar BOD. Hasil yang didapatuntuk satu kali pengolahan disajikan pada Tabel 1.
Tabel 1. Kadar BOD dari Proses pengolahan limbah laundry

\begin{tabular}{llc}
\hline No & Pengolahan & Konsentrasi (mg/l) \\
\hline 1 & Limbah sebelum diolah & 171,95 \\
2 & Bakpenampungan anaerob & 56,66 \\
3 & Biosistem & 44,86 \\
\hline
\end{tabular}

Hasil analisis BOD dari pengolahan dalam Tabel 3.1 diperoleh pada tahap awal merupakan air limbah laundry yang langsung diuji laboratorium tanpa dilakukan pengolahan didapat kadar BOD dari limbah laundry sebesar 171,95 mg/l. Kemudian dilakukan pengolahan pertama dengan cara penggenangan pada bak penampungan anaerob selama 24 jam. Selanjutnya diambil sampel untuk diuji laboratorium didapat hasil ujinya $56,66 \mathrm{mg} / \mathrm{l}$. Hal ini menunjukan bahwa telah terjadi penurunan kadar BOD dari $171,95 \mathrm{mg} / \mathrm{l}$ menjadi 56,66 mg/l disebabkan oleh aktivitas organisme dalam mengoksidasi senyawasenyawa organik yang terdapat pada air limbah laundry. Setelah digenangkan selama 24 jam air limbah laundry kemudian dialirkan kedalam biosistem aliran horizontal,kemudian diambil sampel pada keluaran biosistem untuk diuji di laboratorium, didapat hasil ujinya sebesar 44,86 mg/l. Hal ini menunjukan bahwa terjadi penurunan kadar BOD setelah dialirkan ke biosistem dari $56,66 \mathrm{mg} / \mathrm{l}$ menjadi 44,86 $\mathrm{mg} /$ l, dengan demikian hasil pengolahan menggunakan biosistem yang dipadukan dengan bak penampungan anaerobpada satu kali perlakuan mampu memenuhi baku mutu air limbah yang ditentukan. Penurunan kadar BOD oleh biosistem disebabkan oleh biofiltrasi yang terjadi dalam biosistem dimana tanaman maupun mikroba mampu menghancurkan bahan-bahan pencemar menjadi senyawa yang tidak membahayakan bagi perairan. Pada biosistem ini memanfaatkan akar tanaman rumput gajah sebagai media filtrasialami. Proses filtrasi dari akar tanaman inilah yang mampu mengurangi kadar BOD pada limbah laundry. Hal ini juga didukung oleh penelitian Suyasa dan Dwijani (2007), bahwa unit pengolahan filtrasi berlapis dari pasir dan bebatuan yang dipadukan dengan penyerapan tanaman maupun degradasi oleh mikroba pada risosfir akar akan memberikan hasil efektif bagi pemanfaatan kembali air limbah.Untuk lebih jelasnya penurunan dari kadar BOD pada biosistem yang dipadukan dengan bak penampungan anaerobdalam pengolahan air limbah laundry dapat disajikan pada Gambar 1.

Pada Gambar 1 terlihat bahwa terjadi penurunan kadar BOD selama pengolahan. Pengolahan pertama dengan penggenangan pada bak penampungan anaerob berhasil menurunkan kadar BOD sebesar 115,29 mg/l sedangkan pada pengolahan kedua yaitu dengan menggunakan biosistem mampu 


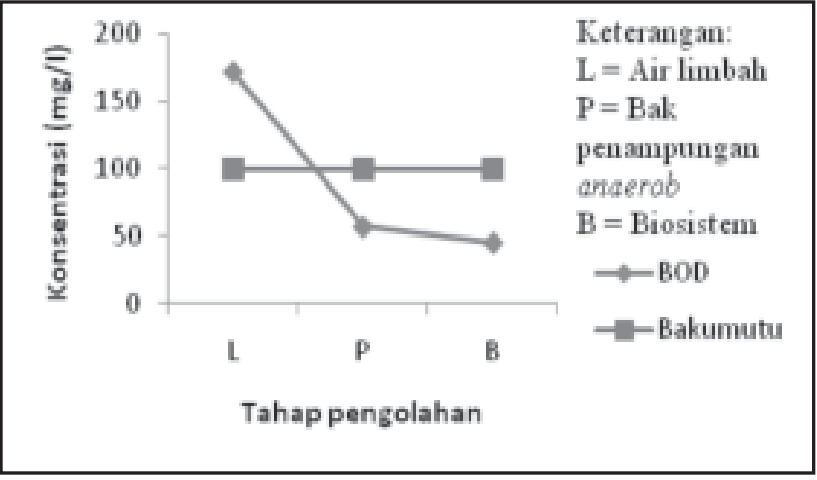

Gambar 1.

Kurva penurunan konsentrasi BOD dari proses pengolahan limbah laundry

menurunkan kadar BOD sebesar 11,8 mg/l. Nilai kadar BOD yang diperoleh tersebut merupakan hasil dari hasil pengolahan menggunakan biosistem yang dipadukan dengan bak penampungan anaerobuntuk mengurangi pencemaran pada air limbah laundry.

\subsubsection{Penurunan Kadar COD}

Chemical Oxygen Demand (COD) atau kebutuhan oksigen kimia (KOK) adalah jumlah oksigen $\left(\mathrm{mg} \mathrm{O}_{2}\right)$ yang dibutuhkan untuk mengoksidasi zat-zat organis yang ada dalam satu liter sampel air, dimana pengoksidasi $\mathrm{K}_{2} \mathrm{Cr}_{2} \mathrm{O}_{7}$ digunakan sebagai sumber oksigen (oxidizing agent) (Alaerts, 1987).

Biosistemyang dipadukan dengan bak penampungan anaerobdigunakan pada penelitian ini mampu menurunkan kadar COD. Hasil pengolahan disajikan pada Tabel 2.

Tabel 2. Kadar COD dari proses pengolahan limbah laundry

\begin{tabular}{llc}
\hline No & Pengolahan & Konsentrasi (mg/l) \\
\hline 1 & Limbah sebelum diolah & 232,76 \\
2 & Bak penampungan anaerob & 80,96 \\
3 & Biosistem & 70,8 \\
\hline
\end{tabular}

Hasil analisis COD dari pengolahan disajikan pada Tabel 2.Pada tahap awal merupakan air limbah laundry yang langsung diuji laboratorium tanpa dilakukan pengolahan didapat konsentrasi COD dari limbah laundry sebesar $232,76 \mathrm{mg} / \mathrm{l}$, kemudian dilakukan pengolahan pertama dengan cara penggenangan pada bak penampungan anaerob selama 24 jam kemudian diambil sampel untuk diuji laboratorium didapat hasil ujinya $80,96 \mathrm{mg} / \mathrm{l}$. Hal ini menunjukan bahwa telah terjadi penurunan kadar COD dari 232,76 mg/l menjadi 80,96 mg/l yang disebabkan oleh aktivitas organisme dalam mengoksidasi senyawa-senyawa kimia yang terdapat pada air limbah laundry. Setelah digenangkan selama 24 jam air limbah laundry kemudian dialirkan kedalam biosistem aliran horizontal kemudian diambil sampel pada keluaran biosistem untuk diuji di laboratorium yang kemudian didapat hasil ujinya sebesar $70,8 \mathrm{mg} / \mathrm{l}$, ini menunjukan bahwa terjadi penurunan kadar COD setelah dialirkan ke biosistem dari 80,96 mg/l menjadi 70,8 $\mathrm{mg} / \mathrm{l}$, dengan demikian hasil pengolahan menggunakan biosistem yang dipadukan dengan bak penampungan anaerobsatu kali perlakuan mampu memenuhi baku mutu air limbah yang ditentukan. Penurunan kadar COD pada penelitian ini didukung oleh Muhammad (2010), penurunan kadar COD diakibatkan oleh mekanisme rhizodegradasi pada biosistem. Rhizodegradasi yang terjadi yaitu oksigen yang dikeluarkan oleh tumbuhan ditransformasikan bersama ke dalam tanah dan oksigen di atmosfer juga ditransportasikan ke dalam daerah akar. Zatzat keluaran akar tumbuhan (eksudat) berfungsi meningkatkan peran mikroorganisme dalam penguraianpolutan dalam tanah. Untuk melihat lebih jelas penurunan dari kadar COD dalam pengolahan air limbah laundry disajikan pada Gambar 2.

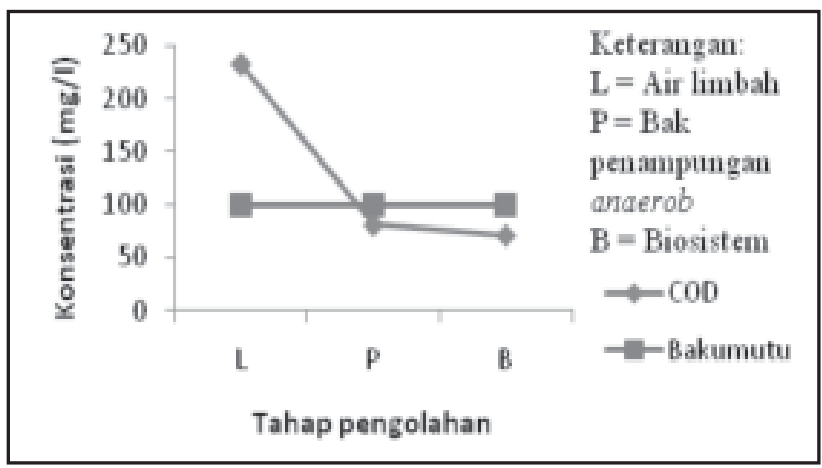

Gambar 2.

Kurva penurunan konsentrasi COD dari proses pengolahan limbah laundry

Pada Gambar 2 terlihat bahwa terjadi penurunan kadar COD selama pengolahan. Pengolahan pertama dengan penggenangan pada bak penampungan anaerob berhasil menurunkan kadar COD sebesar 151,8 mg/l, sedangkan pada pengolahan kedua yaitu dengan menggunakan biosistem mampu menurunkan kadar COD sebesar 10,16 mg/l. Nilai kadar COD yang diperoleh tersebut merupakan ukuran bagi pencemaran air oleh zat-zat organis yang secara ilmiah dapat dioksidasikan melalui proses mikrobiologis dalam biosistem.

\subsubsection{Penurunan Kadar Fosfat}

Senyawa fosfat terdapat dalam bentuk terlarut, tersuspensi atau terikat di dalam sel organisme dalam air. Dalam air limbah senyawa fosfat dapat berasal dari limbah penduduk, industri dan pertanian. Pada aliran sungai daerah perkotaan fosfat masuk melalui drainase pembuangan salah satunya dari usahalaundryyang banyak menggunakan deterjendalampencucian pakaian. 
Pada penelitian ini sudah diuji kemampuan biosistem yang dipadukan dengan bak penampungan anaerobdalam menurunkan kadar fosfat yang terkandung dalam limbah laundry. Hasil pengolahan selama waktu perlakuan disajikan pada Tabel 3.

Tabel 3. Kadar Fosfat dari proses pengolahan limbah laundry

\begin{tabular}{llc}
\hline No & Pengolahan & Konsentrasi (mg/l) \\
\hline 1 & Limbah sebelum diolah & 1,4807 \\
2 & Bak penampungan anaerob & 0,086 \\
3 & Biosistem & 0,6108 \\
\hline
\end{tabular}

Hasil analisis fosfat dari pengolahan dalam Tabel3 diperoleh pada tahap awal merupakan air limbah laundry yang langsung diuji laboratorium tanpa dilakukan pengolahan didapat kadar dari limbah laundry sebesar 1,4807 mg/l kemudian dilakukan pengolahan pertama dengan cara penggenangan pada bak penampungan anaerob selama 24 jam kemudian diambil sampel untuk di uji laboratorium didapat hasil ujinya sebesar 0,086 $\mathrm{mg} / \mathrm{l}$. Hal ini menunjukan bahwa telah terjadi penurunan kadar fosfat dari $1,4807 \mathrm{mg} / \mathrm{l}$ menjadi $0,086 \mathrm{mg} / \mathrm{l}$. Penurunan kadar fosfat dari penggenangan selama 24 jam pada bak anaerob dikarenakan oleh dua hal yaitu stabilitas pengendapat secara biologis dan stabilitas pengendapan secara fisik. Setelah digenangkan selama 24 jam air limbah laundry kemudian dialirkan kedalam biosistem aliran horizontal kemudian diambil sampel pada keluaran biosistem untuk diuji di laboratorium yang kemudian didapat hasil ujinya sebesar $0,6108 \mathrm{mg} / \mathrm{l}$, ini menunjukan bahwa terjadi peningkatan kadar fosfat setelah dialirkan ke biosistem dari 0,086 $\mathrm{mg} / \mathrm{l}$ menjadi $0,6108 \mathrm{mg} / \mathrm{l}$ yangdisebabkan oleh aktivitas organisme dalam biosistem yang melepaskan kadar fosfat dan terjadi pencucian pada akar tanaman yang mengakibatkan lepasnya senyawa fosfat yang terperangkap sebelumnya. Dengan demikian hasil pengolahan menggunakan biosistem yang dipadukan dengan bak penampungan anaerob dengan satu kali perlakuan belum mampu mencapai baku mutu air limbah yang ditentukan. Untuk melihat lebih jelas penurunan kadar fosfat dalam pengolahan air limbah laundry disajikan pada Gambar 3.

Pada Gambar 3 terlihat bahwa pengolahan pertama dengan penggenangan pada bak tertutup anaerobbisa menurunkan kadar fosfat sebesar 1,3947 $\mathrm{mg} / \mathrm{l}$ sedangkan pada pengolahan kedua yaitu dengan menggunakan biosistem kadar fosfat meningkat sebesar $0,5248 \mathrm{mg} / \mathrm{l}$.

\subsubsection{Penurunan Kadar Deterjen}

Deterjen digunakan untuk bahan atau produk yang mempunyai fungsi meningkatkan kemampuan

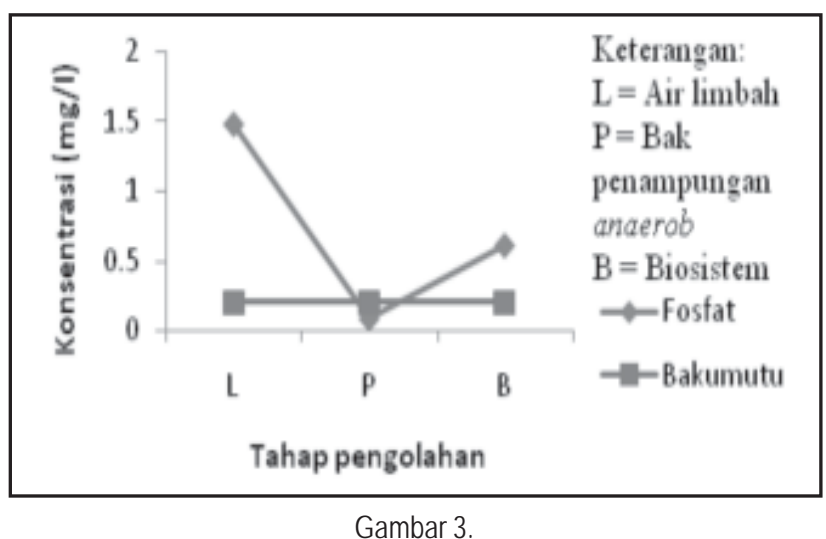

Kurva penurunan konsentrasi fosfat dari proses pengolahan limbah laundry

pemisahan suatu materi dari permukaan benda, misalnya kotoran dari pakaian, sisa makanan dari piring atau buih sabun dari permukaan benda serta mendispersi dan menstabilisasi dalam matriks seperti suspensi butiran minyak dalam fase seperti air (Showell, 2006).

Dengan banyaknya laundry yang membuang air limbahnya ke drainase tanpa dilakukannya pengolahan maka akan terjadi proses eutrofikasi yang menyebabkan alga blooming (meledaknya populasi tanaman air) yang kemudian akan menimbulkan kerusakan pada biota air.

Pada penelitian sudah diuji kemampuan biosistem yang dipadukan dengan bak penampungan anaerob dalam menurunkan kadar deterjen dalam pengolahan selama waktu perlakuan disajikan pada Tabel 4.

Tabel 4. Kadar Deterjen dari proses pengolahan limbah laundry

\begin{tabular}{llc}
\hline No & Pengolahan & Konsentrasi (mg/l) \\
\hline 1 & Limbah sebelum diolah & 1,6528 \\
2 & Bak penampungan anaerob & 0,405 \\
3 & Biosistem & 0,33 \\
\hline
\end{tabular}

Hasil analisis deterjen dari pengolahan dalam Tabel 3.4 diperoleh pada tahap awal merupakan air limbah laundry yang langsung diuji laboratorium tanpa dilakukan pengolahan didapat konsentrasi dari limbah laundry sebesar $1,6528 \mathrm{mg} / \mathrm{l}$ kemudian dilakukan pengolahan pertama dengan cara penggenangan pada bak penampungan anaerob selama 24 jam kemudian diambil sampel untuk di uji laboratorium didapat hasil ujinya $0,405 \mathrm{mg} / \mathrm{l}$. Hal ini menunjukan bahwa telah terjadi penurunan kadar deterjen dari $1,6528 \mathrm{mg} / \mathrm{l}$ menjadi $0,405 \mathrm{mg} / \mathrm{l}$ yangdisebabkan oleh aktivitas organisme dalam mengoksidasi senyawa-senyawa organik yang terdapat pada air limbah laundry. Pada proses penggenangan juga terjadi stabilitas pengendapan baik secara biologis maupun secara fisik. Pengendapan ini juga mempunyai pengaruh yang 
besar terhadap penurunan nilai kadar deterjen pada air limbah laundry. Setelah digenangkan selama 24 jam air limbah laundry kemudian dialirkan kedalam biosistem aliran horizontal kemudian diambil sampel pada keluaran biosistem untuk diuji di laboratorium yang kemudian didapat hasil ujinya sebesar $0,33 \mathrm{mg} /$ l, ini menunjukan bahwa terjadi penurunan kadar deterjen setelah dialirkan ke biosistem dari 0,405 mg/ 1 menjadi 0,33 mg/l,dengan demikian hasil pengolahan menggunakan biosistem dengan satu kali perlakuan mampu memenuhi baku mutu air limbah yang ditentukan. Penurunan kadar deterjen pada keluran biosistem dipengaruhi dari berbagai macam hal salah satunya dengan proses biofiltrasi oleh akar tanaman dan kerikil yang digunakan. Untuk melihat lebih jelas penurunan dari kadar deterjen dalam pengolahan air limbah laundry dapat dilihat pada Gambar 4.

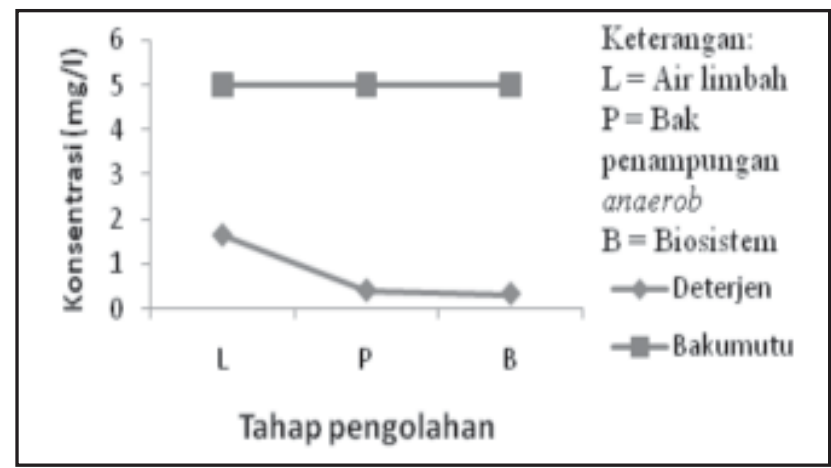

Gambar 4.

Kurva Penurunan Konsentrasi Deterjendari Proses Pengolahan Limbah laundry

Pada Gambar 4 terlihat bahwa terjadi penurunan kadar deterjen selama pengolahan. Pengolahan pertama dengan penggenangan pada bak penampungan anaerob berhasil menurunkan kadar deterjen sebesar $1,2478 \mathrm{mg} / \mathrm{l}$ sedangkan pada pengolahan kedua yaitu dengan menggunakan biosistem mampu menurunkan kadar deterjen sebesar $0,075 \mathrm{mg} / \mathrm{l}$.

\subsubsection{Penurunan $\mathrm{pH}$}

Tingkat keasaman ( $\mathrm{pH}$ ) menunjukan kadar asam atau basa dalam suatu larutan, melalui konsentrasi (aktivitas) ion hidrogen $\left(\mathrm{H}^{+}\right)$. Ion hidrogen merupakan faktor utama untuk mengetahui reaksi kimiawi dalam ilmu teknik penyehatan karena ion hidrogen selalu ada dalam keseimbangan dinamis dengan air. Ion hidrogen membentuk suasana untuk semua reaksi kimiawi yang berkaitan dengan masalah pencemaran air. Sumber ion hidrogen tidak pernah habis dan ion hidrogen tidak hanya merupakan molekul $\mathrm{H}_{2} \mathrm{O}$ saja tetapi juga merupakan unsur senyawa lain, sehingga jumlah reaksi tanpa ion hidrogen dapat dikatakan jumlahnya hanya sedikit (Alaerts, 1987).
Pada penelitian ini juga diuji kemampuan biosistem yang dipadukan dengan bak penampungan anaerob dalam menurunkan $\mathrm{pH}$. $\mathrm{pH}$ dari proses pengolahan selama waktu perlakuan disajikan pada Tabel 5 .

Tabel 5. Tingkat $\mathrm{pH}$ dari proses pengolahan limbah laundry

\begin{tabular}{lll}
\hline No & Pengolahan & pH \\
\hline 1 & Limbah sebelum diolah & 8,28 \\
2 & Bakpenampungan anaerob & 7,91 \\
3 & Biosistem & 7,40 \\
\hline
\end{tabular}

Hasil analisis $\mathrm{pH}$ dari pengolahan dalam Tabel 5 diperoleh yang pertama merupakan air limbah laundry yang langsung diuji laboratorium tanpa dilakukan pengolahan didapat $\mathrm{pH}$ dari limbah laundry sebesar 8,28 kemudian dilakukan pengolahan pertama dengan cara penggenangan pada bak penampungan anaerob selama 24 jam, kemudian diambil sampel untuk diuji laboratorium didapat hasil ujinya 7,91. Hal ini menunjukan bahwa telah terjadi penurunan $\mathrm{pH}$ dari 8,28 menjadi 7,91 yangdisebabkan oleh aktivitas organisme dalam mengoksidasi senyawa-senyawa organik yang terdapat pada air limbah laundry. Setelah digenangkan selama 24 jam air limbah laundry kemudian dialirkan kedalam biosistem aliran horizontal kemudian diambil sampel pada keluaran biosistem untuk diuji di laboratorium yang kemudian didapat hasil ujinya sebesar 7,40 ini menunjukan bahwa terjadi penurunan $\mathrm{pH}$ setelah dialirkan ke biosistem dari 7,91 menjadi 7,40. Untuk melihat lebih jelas penurunan dari kadar $\mathrm{pH}$ dalam pengolahan air limbah laundrydisajikan pada Gambar 5.

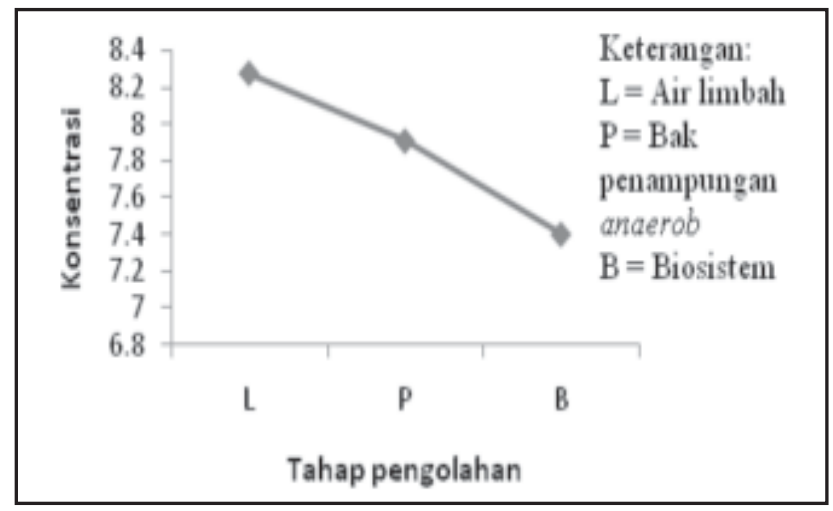

Gambar 5.

Kurva penurunan $\mathrm{pH}$ dari proses pengolahan limbah laundry

Pada Gambar 5 terlihat bahwa terjadi penurunan kadar pH selama pengolahan. Pengolahan pertama dengan penggenangan pada bak anaerob berhasil menurunkan $\mathrm{pH}$ sebesar 0,37 sedangkan pada pengolahan kedua yaitu dengan menggunakan biosistem mampu menurunkan $\mathrm{pH}$ sebesar 0,51. 
3.2 Efektivitas Biosistem yang Dipadukan dengan Bak Penampungan Anaerob dalam Menurunkan KadarBOD, COD, Fosfatdan Deterjen pada Roughing Filter Aliran Horizontaluntuk Pengolahan Air Limbah Laundry

Efektivitas biosistem yang dipadukan dengan bak penampungan anaerob ditentukan dengan membandingkan kadar parameter kualitas air limbahsebelum pengolahan dengan konsentrasi keluaran dari hasil pengolahan biosistem. Efektivitas pengolahandalam menurunkan kadar BOD, COD, fosfatdan deterjen pada roughing filter aliran horizontal untuk pengolahan air limbah laundrydisajikan dalam Tabel 6.

Tabel 6. Efektivitas untuk pengolahan air limbah laundry

\begin{tabular}{llcc}
\hline No & Unsur & $\begin{array}{c}\text { Efektivitas } \\
\text { Biosistem (\%) }\end{array}$ & $\begin{array}{c}\text { Efektivitas } \\
\text { Bakumutu (\%) }\end{array}$ \\
\hline 1 & BOD & 73,91 & 41,843 \\
2 & COD & 69,58 & 57,037 \\
3 & Fosfat & 58,74 & 86,492 \\
4 & Deterjen & 80,03 & 69,748 \\
\hline
\end{tabular}

Berdasarkan Tabel 6 efektivitas dari penurunan kadar BOD, COD, fosfatdan deterjen pada roughing filter aliran horizontal untuk pengolahan air limbah laundry berturut-turut yaitu sebesar 73,91\%, 69,58\%, 58,74\% dan 80,03\%. Berdasarkan hasil tersebut, biosistem yang dipadukan dengan bak penampungan anaerob memiliki efektivitas yang tinggi dalam menurunkan kadar BOD, COD dan deterjen (di atas 50\%) jika dibandingkan dengan efektivitas baku mutu. Ini membuktikan bahwa biosistem yang dipadukan dengan bak penampungan anaerob masih bisa digunakan dalam pengolahan air limbah laundry. Dalam menurunkan kadar fosfat efektivitas dari biosistemyang dipadukan dengan bak penampungan anaerob masih rendah dibandingkan dengan efektivitas baku mutu, dikarenakan terjadinya peningkatan kadar fosfat yang disebabkan dari proses pelepasan fosfat oleh media tanam yang digunakan pada saat air limbah laundry dialirkan kedalam biosistem.

\section{SIMPULAN DAN SARAN}

\subsection{Simpulan}

Berdasarkan hasil penelitian yang telah dilakukan, maka dapat disimpulkan bahwa biosistem yang dipadukan dengan bak penampungan anaerob mampu menurunkan kadar BOD, COD, fosfat dan deterjen sebesar 127,09 mg/L, 161,96 mg/L, 0,8699 $\mathrm{mg} / \mathrm{L}$ dan $1,3228 \mathrm{mg} / \mathrm{L}$ pada roughing filter aliranhorizontal dalam pengolahan air limbah laundry. Kinerja dari komponen fisik dan biologis dalam biosistem yang dipadukan dengan bak penampungan anaerob efektif menurunkan kadar BOD, COD, fosfat dan deterjen berturut-turut sebesar $73,91 \%, 69,58 \%, 58,74 \%$ dan $80,03 \%$ (di atas $50 \%$ ) dalam satu kali perlakuan. Namun hanya dalam menurunkan kadar fosfat efektivitasnya masih tergolong rendah jika dibandingkan dengan efektivitas baku mutu.

\subsection{Saran}

Untuk lebih menyempurnakan penelitian ini masih perlu dilakukan penelitian lebih lanjut untuk menemukan tanaman pada biosistem yang dapat tumbuh dengan subur untuk pengolahan limbah laundry. Perlu dilakukan penelitian lebih lanjut untuk menemukan waktu operasi sampai biosistem mengalami kondisi breaktrough.

\section{DAFTAR PUSTAKA}

Alaerts, G. dan Santika, S.S. 1987. Metoda Penelitain Air. Usaha Nasional. Surabaya.

Muhammad, R. 2010. Biofiltrasi Limbah Perairan. [dikutip 10 Agustus 2016]. Available from:URL:http://muh a m madr 078 . student.ipb.ac.id/2010/06/20/biofiltrasi-limbaherairan.

Pemerintah Provinsi Bali. 2016. Peraturan Gubernur Bali Nomor 16 Tahun 2016 tentang Baku Mutu Lingkungan Hidup dan Kriteria Baku Kerusakan Lingkungan Hidup. Provinsi Bali.

Suyasa, I.W.B. 2015. Pengelolaan air limbah. Denpasar: Udayana Press.

Suyasa, I.W.B., dan Dwijani,W. 2007. Kemampuan Sistem Saringan Pasir-Tanaman Menurunkan Nilai BOD dan COD Air Tercemar Limbah Pencelupan. Jurnal Ecotrophic, Vol: 2 (1), Hal : 1-7.

Suyasa, I.W.B., dan Dwijani,W. 2015. Biosystem Treatment Approach for Seaweed Processing Wastewater. Journal of Environment and Waste Management.Vol. 2(2), page: 059-062. 